\title{
We Have Built it but They Have Not Come: Preliminary Assessment of a Minor in Entrepreneurship
}

\author{
By \\ Gail E. Sype \\ Saginaw Valley State University
}

\begin{abstract}
This paper describes the history and content of a minor in entrepreneurship within the College of Business at a Midwestern (U.S.A.) university. This minor was developed to encourage entrepreneurial development within the region. Enrollment in the minor has been very low. Literature related to the "liability of newness" (Stinchcombe, 1965) and on social capital formation and its influence on new venture success will be reviewed. Recommendations are made for possible program changes.
\end{abstract}

\section{Introduction}

This paper draws on the literature related to entrepreneurship to explore possible reasons why an intrapreneurial venture within a College of Business has failed to produce expected results. The paper reviews literature related to the "liability of newness" (Sacks, 2002; Stinchcombe, 1965) and on social capital formation and its influence on new venture success. Suggestions for new or altered strategies will be derived from that literature.

\section{Legitimacy, Social Capital, and Their Influence on New Ventures:}

Research regarding the development of new ventures (e.g., Stinchcombe, 1965) indicates that new ventures may suffer from a "liability of newness." Stinchcombe's early and subsequent work $(1965,2002)$ contends that new ventures may be less successful because they have few proponents, little is known about them, and this lack of knowledge may lead potential users to perceive a program or service as a more risky choice than better-known and more familiar options. This "liability of newness" (Stinchcombe, 1965) means that the developer of a new venture lacks access to desirable resources such as sources of capital, advice, and even information about potential customers.

If we accept the premise that there is indeed a "liability of newness" associated with new ventures, what can be done to compensate for that liability? Research on entrepreneurs' attempts to develop new ventures indicates that the entrepreneur may need to identify and utilize various sources of social capital in order to generate greater acceptance and support for a new venture. Various authors (e.g., DeCarolis, Litzky \& Eddleston, 2009; Rao, Chandy, \& Prabhu, 2008; Smith \& Lohrke, 2008) indicate that entrepreneurs may compensate for the riskiness of their new ventures by developing 
and drawing upon their social capital to generate resources which will lead the new venture to be perceived as more legitimate. The purpose of this analysis is to review those suggestions and link them to a program in entrepreneurship at a mid-sized university, with the goal of enhancing the reputation and impact of that program.

\section{History and Goals of the Entrepreneurship Minor:}

Between 2002 and 2003 funding was made available to faculty in the College of Business at a mid-sized Midwestern University (hereafter referred to as MWU) to support development of new courses that emphasized entrepreneurship. MWU offers a traditional BBA (Bachelor of Business Administration) program and the new course development activities took place within this degree program. Through funds from a private donor, faculty members were able to apply for support to develop and initially teach the courses that were offered. (The donor wished to support emphasis on entrepreneurship but did not specify what, if any, ultimate outcome or program was desired.) Courses were initially taught as special topics offerings within different departments (Management, Marketing, Finance, etc.). Subsequently, a committee was formed to examine the feasibility of developing an entrepreneurship minor, using the newly-created courses as the core of the program. Individual faculty developed course proposals within their respective disciplines and the courses were combined with existing classes to create the entire minor. The entrepreneurship minor was formally approved by the MWU Business faculty during the 2004-2005 academic year and the College offered the first section of MGT 351 (Introduction to Entrepreneurship) during the Fall 2006 term.

The stated primary goal of creating this program was to encourage more individuals in the region to develop entrepreneurial skills that would benefit the region. It was hoped that the minor in entrepreneurship would enable students to develop the skills necessary to facilitate new product development within existing firms (intrapreneurship) as well as to create new businesses which would contribute to the economic development of the region. One of the reasons for this focus on economic development was that the student base of MWU is substantially local in nature. Many students have family ties in the region and are reluctant to leave the area to seek employment elsewhere.

The goal of creating new economic opportunities is one that is supported by the entrepreneurship literature. Gwynne (2008) notes that individuals with entrepreneurial traits are capable of developing their own businesses and are also attractive to corporate employers. These individuals' abilities to identify and pursue new business opportunities are vital to economic development within a region. Gwynne also indicates that more students are interested in becoming involved in entrepreneurial ventures as a means by which to protect themselves from the turbulence in today's job market. One could presume, then, that students would want to acquire the skills that an entrepreneurial experience would give them. 
A second goal in the creation of the minor was to increase both business and nonbusiness student enrollment within the MWU College of Business. At the minimum, sufficient enrollment to sustain the course offerings (minimum enrollments of 10-15 students per course per semester) was desired. While courses have been offered on a rotating basis since the beginning of the minor, enrollment in the program has been very low. During the most recent academic year only eight students registered for MGT/MKT 459 (Business Plan Seminar), which is the capstone course for the minor. Approximately 20 students have graduated with minors in Entrepreneurship since the program began. It is a source of ongoing frustration for faculty and administrators that this program has not "taken off" and produced more significant results. This paper examines possible reasons why the program has not succeeded to date and explores possible options for reversing this situation.

\section{Structure of the Entrepreneurship Minor:}

The program developed has two sets of requirements: one for business students and one for non-business students. The course requirements for BBA (Bachelor of Business Administration) majors are fewer because those students are already familiar with accounting and finance topics as part of their enrollment in the BBA core. The structure of the program for BBA students is as follows:

Required Courses (6 credits): MGT 351 - 3 credits - Introduction to Entrepreneurship MGT 459 - 3 credits - Business Plan Seminar

Electives: 6 credits from the following:

ECON 356 - 3 credits - Economics for Entrepreneurs MGT/MKT 346 - 3 credits - Franchising (cross-listed in Management and Marketing) MGT 353 - 3 credits - Family Business MGT/MKT 390/490: Special Topics: - 3 credits Entrepreneurship Project

Non-business majors who wish to minor in entrepreneurship must take six additional required credit hours: three credits in ACCT 352 - Accounting for Entrepreneurs and three credits in FIN 311 - Entrepreneurial Finance. Thus, business majors must take 12 credits to fulfill the Entrepreneurship minor and non-business majors must take 18 credits. Of the courses listed above, the MGT/MKT 346 (Franchising), MGT 353 (Family Business), and ECON 356 courses were already present in the undergraduate business curriculum. The rest of the courses were newly created as part of the development of the new program. 


\section{Promotional Strategies related to the Entrepreneurship Minor:}

Low enrollment in the Entrepreneurship minor at MWU has come as a surprise because efforts have in fact been made to publicize the existence of the program. Immediately after the formal approval of the minor, a flyer describing the goals and content of the minor was developed with student and faculty input and was distributed to the campus community. The initial distribution was during the time period immediately after the formal development of the minor, sometime in 2005 or 2006. More recently, a brochure about the program has been developed and is available from the College of Business Dean's office. Additionally, the Entrepreneurship minor is listed as one of the College of Business programs on the University's website, and students can link to a description of the minor from there.

\section{Possible Reasons for Low Enrollment:}

As was indicated above, faculty and administrators within the MWU College of Business had high hopes that the entrepreneurship minor would generate significant student interest across campus. However, enrollment history at MWU indicates that this has not occurred, with limited interest shown in the program by both business and non-business students. Given that the goal of creating this program was and continues to be the development of entrepreneurs and the enhancement of enrollment, what should be done to promote this academic initiative?

\section{Advice from the Entrepreneurship Literature}

Possible lessons regarding actions to be taken can be drawn from the literature on entrepreneurship. Given that the development of a minor in entrepreneurship is in fact an entrepreneurial venture by the College of Business faculty at MWU, the literature on success of entrepreneurial ventures has some relevant advice for us:

\section{The Liability of Newness}

As was indicated above, Stinchcombe's work indicates $(1965,2002)$ that new venture may suffer from a "liability of newness." Stinchcombe's early and subsequent works $(1965,2002)$ contend that new ventures may be less successful because they have few proponents, little is known about them, and this lack of knowledge may lead potential users to perceive a program or service as a more risky choice than known and familiar options. This "liability of newness" (Morse, Fowler, and Lawrence, 2007) means that the developer of a new venture lacks access to desirable resources such as sources of capital, advice, and information about potential customers.

New ventures, such as the minor in entrepreneurship at MWU, may be unfamiliar to potential users and may be avoided because they are perceived as a more risky choice than other options. Since it is relatively new to the MWU academic setting, students in both business and non-business disciplines may know little about the entrepreneurship minor. They may be unwilling to risk investing time and scarce resources (e.g., tuition 
dollars, additional time that may be needed to take courses to complete the minor) in a program that does not promise a known or guaranteed payoff. Similarly, faculty in nonbusiness disciplines may be unwilling to suggest to students that they get involved with a program about which relatively little is known.

If we accept the premise that there is indeed a "liability of newness" associated with this program, what can be done to compensate for that liability? Research on entrepreneurs' attempts to develop new ventures indicates that the entrepreneur may need to identify and utilize various sources of social capital in order to generate greater acceptance and support for a new venture. Various authors (e.g., DeCarolis, Litzky \& Eddleston, 2009; Rao, Chandy, \& Prabhu, 2008; Smith and Lohrke, 2008) indicate that entrepreneurs may compensate for the riskiness of their new ventures by developing and drawing upon their social capital to generate resources which lead the new venture to be perceived as more legitimate.

For example, Rao et al. (2008) draw on Suchman (1995, p. 574) in defining legitimacy as "a generalized perception or assumption that the actions of an entity are desirable." Describing legitimacy in the context of new venture creation, Rao et al. contend that enhancing the perceived legitimacy of a new venture will make that venture more appealing to stakeholders (such as potential investors, customers or users). Rao et al. indicate that legitimacy is drawn from either internal (within the organization) or external (outside the organization) sources. According to Rao et al, internal sources of legitimacy include:

1. Location: A firm has a location advantage when it can prove it has a geographic advantage of some sort, such as proximity to successful producers or to major customers. In terms of proximity to "successful producers," MWU does not enjoy such an advantage at the present time. In fact, currently the area surrounding MWU is in a state of change. Historically the area has been dependent upon auto-related businesses, which are currently in a state of decline. So the MWU College of Business cannot point to any currently successful local businesses with which it is affiliated and from which it can draw status.

Additionally, MWU may also be able to overcome a possible location disadvantage if it reaches out to the local community to develop ties. If the MWU College of Business were to identify a well-known local entrepreneur, who was willing to endorse the program that might enhance the perceived legitimacy of the Entrepreneurship minor, we would then have an advantage in terms of the desirability of the Entrepreneurship minor relative to local preferences.

2. History: The firm has an advantage if it can prove it has had a history of successful new product introductions in the past. Most new ventures do not have such a history to draw on (Rao et al. 2008), and thus lack historical sources of legitimacy. In the case of the MWU College of Business, there is a limited history of successful "new product introduction" to draw on. A short time prior to the introduction of the Entrepreneurship minor, a program in International Business 
was introduced. That program is headed up by a visible champion (an endowed chair in global business) and the program has been successful, drawing both majors and minors and attracting successful students. Significant effort was put into the development and publicizing of this program, with social networking taking place across affected departments, and with workshops being offered to students to enable them to find jobs in international business after graduation. Perhaps the specific history of the International Business major and minor should be examined to identify specific tactics that were used to boost prestige and enrollment.

3. Scientific legitimacy: The firm can develop an advantage if it can prove that it possesses the technological capacity to succeed, perhaps by putting eminent scientists on the board of directors. The International Business program described above may have benefitted from the prestige of the individual(s) in charge. While there is a committee in charge of the Entrepreneurship minor, the individuals on this committee are neither as visible nor as well known to the campus community. Membership on this committee has also changed over time, with limited opportunities to develop a visible image based on any one individual's affiliation with the program. Perhaps an attempt should be made to either enhance the legitimacy of the current representatives of the minor or to find a new, more visible "champion" for the program.

4. Market-oriented: Market-oriented legitimacy can be generated when the firm can show that it understands the needs of the market, for example placing successful executives from other organizations on its board of directors. This demonstrates to internal and external stakeholders that the organization understands and is responsive to their needs. The Entrepreneurship committee which oversees the minor is comprised entirely of faculty from within the College of Business. While these faculty members are well-regarded within their fields, none of them hold a degree in the field of Entrepreneurship. Further, there are no active entrepreneurs represented on the committee. It may be that an Entrepreneurship advisory board should be created with successful entrepreneurs (particularly alumni) from the community to provide advice and support.

Rao et al. (2008) also contend that a new venture can achieve legitimacy through external sources, i.e., alliances with better-known or more prestigious firms. The MWU Entrepreneurship minor does not have any alliances at the present time; it is not linked to any community or business organizations. No efforts have been made to encourage community members to enroll in the Entrepreneurship minor. However, there are ways to access sources of external legitimacy: For example, there are entrepreneurship organizations that could provide legitimacy through grants, contracts or alliances (e.g., the Kauffman Foundation, USAUSGE, etc.). The use of an advisory committee comprised of members of the regional business community or other recognized external source would help generate legitimacy both on a market-based and an externally-based level. 
Legitimacy is also raised as a concern by Katz (2008), albeit in a different context. Katz' contention is that entrepreneurship as an academic field lacks legitimacy in that it is not viewed as a "taken-for-granted" or widely accepted field. The evidence provided for this is that entrepreneurship as a field lacks scholars who are specifically trained in the discipline; universities may look askance at scholars who publish only in the field of entrepreneurship; and scholars in entrepreneurship generally do not rise into the ranks of deans. Entrepreneurship in academia, Katz claims, cannot claim to be as fully recognized a discipline as say, finance or marketing.

Katz's view is not shared by all scholars. Numerous surveys have traced the rapid growth of the field in terms of new entrepreneurship degree programs and number of entrepreneurship Ph.D. programs (Cooper, 2003). Additionally, scholars have noted the growth of studies in entrepreneurial academic sub-disciplines of international entrepreneurship (Etemad \& Wright, 2003; Puia, 2009) social entrepreneurship (Zahra et al., 2009) and intrapreneurship (Audretsch, 2009).

Specifically, Cooper (2003) contends that entrepreneurship is a recognized and accepted field in its own right. However, even if entrepreneurship is in fact a legitimate academic discipline, that perceived legitimacy only extends as far as others' knowledge and understanding permits it to. If students or other faculty are unfamiliar with the field of entrepreneurship, this lack of awareness may play a role in the problems faced by the entrepreneurship minor at MWU. Students and faculty in non-business disciplines may not know much about entrepreneurship and may be skeptical of its value as a minor. In fact, students may not even know what the term "entrepreneurship" refers to! This would prove a significant barrier to effective student recruitment.

To resolve this lack of legitimacy, we may also need to enhance our promotion of the entrepreneurship program. Brochures and program descriptions need to clarify the purpose and expected student outcomes of the program. Examples of ways in which students could use their education must be provided. Profiles of successful alumnieither MWU alumni who have succeeded as entrepreneurs or alumni of the minor itself - should be used to illustrate the value of entrepreneurial skills in the wider marketplace.

Useful advice regarding enhancement of program legitimacy may also be obtained from the work of Smith and Lohrke (2008). Smith and Lohrke looked at the experiences of entrepreneurs in founding new ventures and assessed how those entrepreneurs used their social capital (their interpersonal resources and networks) to acquire valuable resources (such as emotional or financial support for the venture). In their study of the role of trust in the development of a network of relationships between an entrepreneur and his or her contacts, they found that the type of trust that was most important varies over time. Their results indicate that in the early stages of a relationship, affective or emotional trust is most important, and more trust (i.e., a stronger relationship) exists between people who know one another. That affective trust may help individuals to develop relationships which lead them to productive exchanges with resource providers. As they develop a history of successful exchanges, cognitive (or rationally-based) trust 
can grow to augment or supplant affective trust as the two sides develop a history of successful interactions and come to find each others' behaviors predictable.

DeCarolis et al. (2009) further delineate the role of networks and social capital in the formation and progress of new ventures. They define a social network as "the number of informal and formal ties that an individual has" (2009, p. 530) and indicated that larger social networks enable entrepreneurs to respond better to environmental opportunities. DeCarolis et al. (2009) define relational capital as the nature of the personal relationships [entrepreneurs] have developed through interactions. So successful entrepreneurs have both wide networks and strong connections with individuals who can serve as resources. If we apply this insight to the development of the Entrepreneurship minor at MWU, we find that in the founding of the program at MWU, only business faculty were involved in the development and promotion of the minor. While written promotions were used to advertise the existence of the minor, very limited networking took place across campus. If new ventures rely, at least initially, on interpersonal trust for acceptance, the MWU business faculty needed to, and will continue to need to, reach out to a broader network of faculty colleagues, and to colleagues with whom they have the closest ties or the longest relationships. The College of Business faculty will need to ask colleagues in other departments and divisions to refer students to the minor; College of Business faculty may need to make presentations to groups of students from other divisions; in general, the College of Business faculty will need to utilize their social capital in order to make the Entrepreneurship minor more visible and more legitimate across campus. This extension of social capital networks goes beyond simple promotional activities. Business faculty may need to ask friends and colleagues in other departments to provide valuable resources, such as time in their classes to promote the program and formal endorsements of its content. Further, they may be consulted on revisions or enhancements to program content to match the needs of non-business students. Finally, the social network may provide an opportunity for students in the entrepreneurship minor to demonstrate their talents by working on applied projects in other disciplines.

If social capital is to be used most effectively, the individuals with the greatest social capital should be called upon to promote the minor. Individuals with high levels of social capital (e.g., well regarded by their peers) may serve as a unique resource. It may be that the College of Business needed to identify those faculty who are most highly regarded within the University community and may want to "engage" those individuals to serve as advocates for the Entrepreneurship minor across campus. This social capital strategy would also dovetail with the findings of Hambrick and Chen (2008).

Hambrick and Chen, in a review of how new academic fields emerge, indicate that there is a need for further research on the "intrafield political dynamics" of social movements i.e., a need to understand how the emergence of leader(s) influences the dynamics of a social movement. MWU may need to focus more explicitly on leadership of the Entrepreneurship minor in order to determine how to make the minor more visible and attractive. 
Smith and Lohrke's (2008) assessment of the role of trust in developing entrepreneurial ventures indicates that as exchanges between an entrepreneur and his or her network proceed, affective trust may be replaced or supplemented by cognitive trust, which is based on one's assessment of the utility of exchanges that have taken place. At the present time all of the courses in the minor are courses taught within the College of Business. There is currently an informal dialogue taking place about if and how courses might need to be modified to meet the needs of specific students from other disciplines. Much as entrepreneurs need to tailor their products to their market, we may need to adapt the Entrepreneurship minor to the needs of specific groups of students or specific majors within the University. Scheduling of classes, topics covered in classes, and types of organizations served may need to vary according to the interests of the students in the program. This may require the program to change over time or to develop a series of elective courses that may vary with student backgrounds.

Marvel and Lumpkin, 2007, assessed the formation of new ventures and pointed out specific factors that can influence that process. Similar to Yu (1991), they advance the notion of the possible influence of a "knowledge corridor" - a cognitive bias or mindset wherein one's prior knowledge leads one down a corridor that involves recognition of one set of opportunities and not of others. They also found in their research that an entrepreneur's breadth of work experience influenced the type and extent of opportunities that the entrepreneur could recognize and utilize. It is possible that our Entrepreneurship minor, developed with only faculty oversight, may have failed to recognize possibilities in the regional business community that could be taken advantage of, or overlooked non-academic stakeholders that could be served by the program. Perhaps we need to reach out to the local Chamber of Commerce or to our alumni to determine whether there are elements of an entrepreneurship program that we could develop which meet their specific needs.

\section{Recommendations:}

Given the insights of the research summarized above, there are a number of possible actions which could be taken to enhance the visibility and perceived legitimacy of the Entrepreneurship minor at MidWest University:

1. To enhance the program's perceived legitimacy: Utilize an entrepreneurial advisory board to enable the program to offer activities and classes that are tied to stakeholder needs. A link to entrepreneurs in the community would enhance the legitimacy of the program (Rao et al., 2008) and would also enhance the educational experience for students participating in the minor (Edelman et al., 2008). Development and use of an entrepreneurial advisory board would also create a situation where more community-based and regional opportunities would be recognized and capitalized upon (Marvel \& Lumpkin, 2007). Finally, an advisory board could also help us identify ways to package the minor to make it more appealing to non-traditional students such as would-be entrepreneurs. For example, perhaps the minor could be offered in one- or two-credit hour modules, 
perhaps offered over a series of weekends, rather than in the traditional fifteenweek academic package.

2. Utilize strategies found successful by other academic programs: To benefit from historical legitimacy (Rao et al., 2008): Examine the history of the creation of the International Business major and minor at MWU to identify specific tactics that could be used to enhance the legitimacy of the Entrepreneurship minor. Adapt specific techniques to the introduction and promotion of the Entrepreneurship program.

3. Assess and alter promotional materials: To enhance our market-based and external legitimacy (Rao et al., 2008): Review and adapt the promotional literature which encourages students to consider minoring in Entrepreneurship. Use testimonials and profiles of successful alumni to illustrate the program's value to a student's career preparation.

4. Identify social capital that can be utilized: To enhance the program's overall legitimacy: Identify faculty with significant social capital (e.g., highly respected inside and outside the College of Business) and encourage these faculty to serve as advocates for the Entrepreneurship minor. Further, this same social capital network can serve as a source of innovation in program content and delivery, since these individuals are experts in the major fields from which students will be drawn. Both business and non-business faculty may need an orientation on the specifics of the minor in order to serve as effective representatives and advocates.

5. Enhance others' utilities derived from their exchanges with the Entrepreneurship minor: Develop an exchange-based framework which allows course offerings to be modified depending on the needs of students and/or faculty from other disciplines throughout the University. Make adaptations in courses, topical coverage, etc., to ensure benefits are perceived by stakeholders outside the College of Business.

\section{Future Questions:}

Listed above are a series of possible actions which could be used to enhance the reputation and image of the Entrepreneurship minor at MWU. These possible actions are derived from research related to the development of new ventures. However, these insights look to the "real world" of entrepreneurial activity and not to the specific world of academia. There are a number of issues that could be looked at in the academic context to gain additional insight:

- Do similar programs exist elsewhere? How successful are these programs at recruiting and retaining students? What advice do administrators of these programs offer for the Entrepreneurship minor at MWU? 
- In similar situations, are there strategies that were used to facilitate cooperation by faculty from other disciplines? Are there benefits or incentives that can be offered to faculty in other disciplines, to encourage their support of the program? - Are there examples of programs that have built ties to the regional business community? What was the impact of community linkages on program success?

In sum, a number of insights can be gained from the entrepreneurship literature on legitimacy and social capital which can be used to make recommendations about enhancing the visibility and vitality of the Entrepreneurship minor at MWU. Any suggestions or insights that readers can offer would be greatly appreciated.

\section{A Brief Epilogue:}

In recent changes to the administrative structure of the MWU College of Business, a new alliance was formed. The College of Business now is working more closely with a subunit of MWU that provides service and support to local businesses. An individual working within that outreach unit, who has a specific background in entrepreneurship and local economic development, will now be working half-time within the College of Business. One of this individual's priorities will be outreach to the greater campus community on behalf of the minor in Entrepreneurship. A series of public meetings have been scheduled to provide information and "persuasion" to students interested in the minor. The College of Business has decided to utilize a "champion" for the program and time will tell whether this strategy will pay off in terms of increased enrollments.

\section{References}

Audretsch, D. (2009). Emergence of the entrepreneurial society. Business Horizons, 52(5), 505-511.

Cooper, A. (2003). Entrepreneurship: The past, the present, the future. In Z. T. Acs and D. B. Audretch (Eds.), Handbook of Entrepreneurship Research (pp. 21-34). London, UK: Kluwer Academic Publishers.

DeCarolis, D. M., B. E. Litzky, \& K. A. Eddleston. (2009). Why networks enhance the progress of new venture creation: The influence of social capital and cognition. Entrepreneurship: Theory and Practice, 33(2), 527-545.

Gwynne, P. (2008). More schools teaching entrepreneurship. Research Technology Management, 51(2), 6-8.

Hambrick, D. C., \& Chen, M-J. (2008). New academic fields as admittance-seeking social movements: The case of strategic management. Academy of Management Review, 33(1), 32-54.

Katz, J. A. (2008). Fully mature but not fully legitimate: A different perspective on the state of entrepreneurship education. Journal of Small Business Management, 46(4), 550-566.

Marvel, M. R., \& Lumpkin, G. T. (2007). Technology entrepreneurs' human capital and its effects on innovation radicalness. In Entrepreneurship: Theory and Practice, 31(6), 807-828. 
Morse, E. A., S. W. Fowler \& T. B. Lawrence. (2007). The impact of virtual embeddedness on new venture survival: Overcoming the liability of newness. Entrepreneurship: Theory and Practice, 31(2), 139-159.

Puia, G. M. (2009). International entrepreneurship and international business. In S. M. Carraher and D. H. B. Walsh (Eds.), Global entrepreneurship (pp. 3-31). Dubuque, IA: Kendall-Hunt Publishers.

Rao, R. S., Chandy, R., \& Prabhu, J. (2008). The fruits of legitimacy: Why some new ventures gain more from innovation than others. Journal of Marketing, 72(4). 5875.

Sacks, M. A. (2002). The social structure of new venture funding: Stratification and the differential liability of newness. Social Structure and Organizations (Revisited) 19, 263-294.

Smith, D. A., \& Lohrke, F. T. (2008). Entrepreneurial network development: Trusting in the process. Journal of Business Research, 61(4), 315-322.

Stinchcombe, A. L. (1965). Social structure and organizations. In J. G. March (Ed.), Handbook of organizations (pp. 142-193). Chicago, IL: Rand McNally and Co.

Stinchcombe, A. L. (2002). New sociological microfoundations for organizational theory: A postscript. In M. Lounsbury and M. J. Ventresca (Eds.), Research in the sociology of organizations (pp. 425-443). Oxford, U.K.: JAI Press.

Suchman, M. C. (1995). Managing legitimacy: Strategic and institutional approaches. Academy of Management Review, 20(3), 571-610.

Yu, P. I. (1991). Habitual domains. Operations Research, 39(6), 869-877.

Zahra, S., Gedajlovic, E., Neubaum, D., \& Shulman, J. (2009). A typology of social entrepreneurs: Motives, search processes and ethical challenges. Journal of Business Venturing, 24(5), 519-532. 